\title{
Changing One's Tune: Re-reading the Structure of Psalm 132 as Complex Antiphony ${ }^{1}$
}

\author{
Wen-Pin LeOW (Wycliffe Hall, UNiversity of OXFORd)
}

\begin{abstract}
Complex antiphony, which allows dialogue between non-linearly adjacent cola in a psalm, provides the potential for re-reading problematic Hebrew texts such as Psalm 132. This article studies the two main structural options that have been proposed for Psalm 132, arguing in preference for the minority view that places a major break after v. 9. It is then argued, based on this minority structure, that the multiple distinctive types of literary bonds between the two halves of the psalm point towards a form of complex antiphony known as steady responsa. It is then shown that such a steady responsa reading of Psalm 132 addresses some of the critical exegetical problems of the psalm, such as the referent of the pronominal suffixes in $v$. 6 . In addition, this reading also reveals a coherent and rich petitionary rhetoric in Psalm 132.
\end{abstract}

KEYWORDS: Antiphony, Steady responsa, Non-linear Structure, Psalm 132

\section{A INTRODUCTION}

Antiphony, the mode of song where two sets of voices sing alternatively, is a common phenomenon attested to in the Hebrew Bible (HB) and in literature from the ancient Near East. ${ }^{2}$ The simplest form of antiphony is plain antiphony where the successive cola of a psalm are sung in an alternating fashion by two voices. ${ }^{3}$ As this form of antiphony follows the verse sequence of the Hebrew text, it

* Submitted: 20/09/2018; peer-reviewed: 01/10/2018; accepted: 19/02/2019. WenPin Leow, "Changing One's Tune: Re-reading the Structure of Psalm 132 as Complex Antiphony," Old Testament Essays 32 no. 1 (2019): 32-57. DOI: https://doi.org/ 10.17159/2312-3621/2019/v32n1a4.

1 This author would like to express grateful thanks to Dr Peter C. W. Ho for his insightful comments on an earlier draft of this paper.

2 For the former, see Israel W. Slotki, "Antiphony in Ancient Hebrew Poetry," JQR 26.3 (1936): 199-219. For the latter, see Nissim Amzallag and Shamir Yona, "The Unusual Mode of Editing of KTU 1.65," UF 45 (2014): 35-48 as well as nn. 4 and 5 in Nissim Amzallag and Mikhal Avriel, "Complex Antiphony in Psalms 121, 126 and 128: The Steady Responsa Hypothesis," OTE 23.3 (2010): 503.

3 Amzallag and Avriel, "Complex Antiphony," 503. 
usually does not produce innovative exegetical insights. Recently, more sophisticated forms of antiphony known collectively as complex antiphony have been investigated, primarily through the work of Nissim Amzallag with his collaborators Yona Shamir and Mikhal Avriel. ${ }^{4}$ Since "the choral dialogue occurs between non-adjacent fragments of text" in complex antiphony, it often yields considerably different interpretations when compared to linear readings of the text.

Complex antiphony thus offers a sizeable potential for re-reading problematic Hebrew texts in the hope that solutions might be obtained based on novel antiphonal structures. (This is provided, of course, that the text itself suggests such antiphonal structures.) Psalm 132 is one example of such a problem text. There is, for example, a long-standing scholarly debate regarding the division of the text, with the majority of interpreters placing a major break after v. 10 in contrast to a minority who argue for doing so after v. $9 .{ }^{6}$ In addition to this structural problem are the numerous semantic and syntactical problems in the psalm, chief of which is the problem of identifying the referent for the feminine pronominal suffixes in v. $6 .^{7}$

This article proposes to resolve the abovementioned difficulties in Psalm 132 through a complex antiphonal reading. The discussion will be in four parts. First, since complex antiphonal arguments are predicated on understanding structure in a non-linear way, the arguments supporting the majority (linear) view of the structure of the psalm will be interrogated and shown to be wanting. Second, arguments will then be put forth for the superiority of the minority view of the psalm's structure. Third, it will then be argued that the structural correspondences evident in the minority view point towards a particular mode of

4 In addition to the articles cited in n. 2, see also Nissim Amzallag, "The Musical Mode of Writing of the Psalms and Its Significance," OTE 27.1 (2014): 17-40; "Psalm 87 and the Cosmopolitan Musical Worship of YHWH," VT 64 (2014): 361-81; "The Meaning of Todah in the Title of Psalm 100," ZAW 126.4 (2014): 535-45; "Praise or Antiphonal Singing?: The Meaning of להודות Revisited," HS 56.1 (2015): 115-28; "Psalm 67 and the Cosmopolite Musical Worship of YHWH," BBR 25 (2015): 31-48; "Foreign Yahwistic Singers in the Jerusalem Temple?: Evidence from Psalm 92," SJOT 31.2 (2017): 213-35; Nissim Amzallag and Mikhal Avriel, "The Canonic Responsa Reading of Psalm 114 and Its Theological Significance," OTE 24 (2011): 303-23; "Responsive Voices in the Song of the Sea (Exodus 15:1-21)," JBQ 40.4 (2012): 21124; "Psalm 122 as the Song Performed at the Ceremony of Dedication of the City Wall of Jerusalem (Nehemiah 12,27-43)," SJOT 30.1 (2016): 44-64; Nissim Amzallag and Shamir Yona, "What Does 'Maskil' in the Heading of a Psalm Mean?," ANES 53 (2016): 41-57;

5 Amzallag and Avriel, "Complex Antiphony," 503.

6 See Gianni Barbiero, "Psalm 132: A Prayer of 'Solomon'," CBQ 75.2 (2013): 240.

7 Frank-Lothar Hossfeld and Erich Zenger, Psalm 3: A Commentary on Psalms 101150, trans. Linda M. Maloney, Hermeneia (Minneapolis: Fortress, 2011), 455-56. 
complex antiphony, namely, steady responsa. In order to argue this, specific criteria to determine steady responsa, based on those which were earlier established by studies on complex antiphony elsewhere in the HB by Amzallag and his colleagues, will first be articulated. Thereafter, the psalm (read according to the minority view) will be studied to show that it does meet these criteria, thus demonstrating that the psalm is indeed best understood as steady responsa. Along the way, solutions for the aforementioned exegetical problems will emerge from the antiphonal analysis. Fourth, the psalm will then be re-examined to show that the antiphony creates a coherent and compelling rhetoric.

\section{B THE MAJORITY VIEW OF THE STRUCTURE OF PSALM 132}

Zenger neatly summarises the main structural debate of Psalm 132: "Nearly all authors posit a fundamental division of the psalm into two parts ... However, it is disputed whether the caesura should be taken to occur before or after v. 10." The latter, where the two stanzas of the psalm are regarded as vv. 1b-10 (Stanza 1) and vv. 11-18 (Stanza 2), is the majority view. ${ }^{9}$ Some advocates further elaborate upon the majority view via a division of each stanza into multiple strophes, e.g., Huwiler (vv. 1b-7b, 8a-10b, 11a-12b, 13a-18b) and Barbiero (vv. $1 b-5 b, 6 a-10 b, 11 a-12 d, 13 a-18 b) .{ }^{10}$ In order to evaluate the validity of the majority view, the supporting evidence proposed by its proponents must be collated and evaluated. There are at least twelve such arguments that have been advanced (labelled in the following discussion as " $\# 1$ " to "\#12"), which can be organised according to textual semantic-syntactic, thematic-cohesive, and formbased categories.

Three caveats need to be made at this point. First, these three categories are suggested for ease of discussion. However, this does not preclude some

$8 \quad$ Hossfeld and Zenger, Psalms 3, 457.

9 See for example, Leslie C. Allen, Psalms 101-150, Revised ed., WBC 21 (Waco, TX: Word, 2002), 264; Thijs Booij, "Psalm 132: Zion's Well-Being," Biblica 90.1 (2009): 75; Walter Brueggemann and William H. Jr. Bellinger, Psalms, NCBC (New York: Cambridge University Press, 2014), 556; Loren D. Crow, Songs of Ascents (Psalms 120-134): Their Place in Israelite History and Religion, SBLDS 148 (Atlanta: SBL Press, 1996), 104; Erhard S. Gerstenberger, Psalms, Part 2, and Lamentations, FOTL 15 (Grand Rapids: Eerdmans, 2001), 366; Hermann Gunkel, Die Psalmen (Göttingen: Vandenhoeck \& Ruprecht, 1929), 567; Hossfeld and Zenger, Psalms 3, 458; Elizabeth F. Huwiler, "Patterns and Problems in Psalm 132," in Listening Heart: Essays in Wisdom and the Psalms in Honor of Roland E. Murphy, ed. Kenneth G. Hoglund, JSOTSup 58 (Sheffield: Sheffield Academic, 1987), 201-2; Heinz Kruse, "Psalm 132 and the Royal Zion Festival," VT 33.3 (1983): 280-81; Antti Laato, "Psalm 132 and the Development of the Jerusalemite/Israelite Royal Ideology," CBQ 54.1 (1992): 50; James Luther Mays, Psalms, IBC (Louisville: Westminster John Knox, 1994), 410; Artur Weiser, The Psalms: A Commentary, trans. Herbert Hartwell, OTL (Philadelphia, PA: Westminster, 1962), 779-80.

10 Huwiler, "Patterns and Problems," 201; Barbiero, "Psalm 132," 241. 
arguments from falling into more than one category. Second, due to the aforementioned further subdivision of the two stanzas into strophes, commentators often conflate arguments about cohesion between strophes with their arguments for their preferred stanzaic division. However, since minority view advocates also support the presence of similar strophes, such arguments cannot differentiate between the majority and minority views on the stanzaic divisions unless they involve v. 10 or v. $11 \mathrm{ab}$. Thus, arguments that do not involve v. 10 and v. $11 \mathrm{ab}$ have been omitted from this discussion. ${ }^{11}$ Third, since these twelve arguments appear in the works of many different commentators, in order to avoid excessive footnotes, the citations in the rest of this section refer mostly to two major articles on the structure of Psalm 132 by Huwiler and Barbiero respectively. ${ }^{12}$

Let us begin by considering the textual semantic or syntactic arguments. Huwiler argues (\#1) that the repetition of the formula "inflected verb + יהוה + preposition + noun" marks the start of strophes. ${ }^{13}$ The use of the formula in vv. 11a means that the stanzaic caesura must be after v. 10 (i.e., the majority view). However, the distinctiveness of this so-called formula is undermined by its verbsubject-object order being the preponderant word order among finite clauses in the HB. ${ }^{14}$ Thus, the syntactical structure of the formula is unremarkable. Moreover, the term יהוה is also an exceedingly common term in the HB, and it also appears in vv. $2 \mathrm{a}$ and 5a. ${ }^{15}$ Another significant problem with the so-called formula is in v. 13 where the verb is preceded by the particle $כ$, which violates the proposed formula. Huwiler, appealing to the work of Stephen A. Geller, argues that such particles are "'grammatical elements' which do not affect parallel structures." ${ }^{16}$ However, Geller only makes this observation for the limited corpus of early biblical poetry which he studies (which does not include Psalm 132) ${ }^{17}$ It can be seen from numerous other examples in the Psalter that

11 Thus, for example, some of Barbiero's arguments (cf., "Psalm 132," 241-242) can be omitted.

12 Huwiler, "Patterns and Problems," and Barbiero, "Psalm 132."

13 Huwiler, "Patterns and Problems," 201.

14 Adina Moshavi, Word Order in the Biblical Hebrew Finite Clause, LSAWS 4 (Winona Lake, IN: Eisenbrauns, 2010), 11-13.

15 Huwiler ("Patterns and Problems," 201) tries to fend off this objection by pointing out that יהוה is used syntactically as an accusative (marked by ל) in these two instances rather than as a nominative as in the formula. While this is true, the very presence of these two additional occurrences still weakens the distinctiveness of יהוה in the so-called formula.

16 See Huwiler, "Patterns and Problems," 201 who cites, in support of her argument, Stephen A. Geller, Parallelism in Early Biblical Poetry, HSM 20 (Missoula, MT: Scholars Press, 1979), 6-7.

17 The only psalms which Geller studies are Pss 18; 24; 29; 68; 77 (v. 17 only); 89; 114, cf., Geller, Parallelism, 53. 
this observation is not generally true of ${ }^{18}{ }^{18}$ Moreover, Huwiler does not mention that Geller also treats prepositions as grammatical elements which are ignored in parallel structures. ${ }^{19}$ If one consistently applied Geller, this would further erode the distinctiveness of the so-called formula. Thus, the argument to omit כי consideration of the formula cannot be consistently sustained. ${ }^{20}$

Another argument (\#2) proposed by Huwiler is that each strophe begins with a verb form that is then modified by the end of the strophe: imperative $\rightarrow$ cohortative (vv. 1b-7b); imperative $\rightarrow$ negative imperative (8a-10b); perfect indicatives $\rightarrow$ imperfect indicatives (11a-12b;13a-18b). These strophic divisions are then claimed to reinforce Huwiler's preferred stanzaic division. ${ }^{21}$ However, this appears to be a case of special pleading, since the norm in biblical scholarship is to recognise the repetition of verbal syntactic forms as cohesion (rather than the opposite, that is, changes in syntactical form) ${ }^{22}$ Moreover, some of the intra-strophic verb changes strike one as unrelated to each other and are thus likely incidental, e.g., the shift from a nip'al qatal verb in v. 11a to a qal yiqtol verb in $\mathrm{v} .12 \mathrm{~d}$ (which is further weakened by the fact that $\mathrm{v} .11 \mathrm{~b}$ has a qal yiqtol verb). If one wished to be generous, one might perhaps allow for these socalled changes to be used as discourse markers if the paired verb forms were from the same root or from similar semantic fields, but this is not even the case.

A third argument (\#3) is suggested by Barbiero. ${ }^{23}$ Observing that the proper noun דוד appears four times in the Psalm in vv. 1b, 10a, 11a, and 17a, these occurrences are claimed to form two inclusios which demarcate the starts and endings of each of two stanzas (vv.1b-10b and vv.11a-18b). Unlike the use דוד in the first argument, this argument is more distinctive since יהוה in there is only used in the four verses cited. However, this argument is marred by an unconvincing second inclusio pair (v. 11a and v. 17a). There is minimal correspondence in language between the lines beyond the use of לדוד. Moreover,

18 Consider, for example, the five-fold use of כi Ps 135:3-5. It is clear that, in this instance, the deliberate repetition of כי כי supports the parallelism in creating cohesion across those verses. See also the use of in the parallel pairs in Pss 6:3; 8:5; 102:14; 142:7; 143:8. See also n. 47.

19 Geller, Parallelism, 6-7.

20 Other than the problems with the formula itself, the use of this formula as a strophic marker results in the first strophe being vv. 1b-7b. However, a vast majority of commentators see a distinct shift between v. 5 and v. 6 (even other majority view advocates).

21 Huwiler, "Patterns and Problems," 201-2.

22 See Elizabeth Robar, "Coherence and Cohesion," EHLL 1:472-476 [474] and Pieter van der Lugt, Cantos and Strophes in Biblical Hebrew Poetry with Special Reference to the First Book of the Psalter, OTS 53 (Leiden: Brill, 2006), 81-84.

23 Barbiero, "Psalm 132," 240. 
the last instance of דוד appears in the second last verse of Stanza 2 (v. 17) rather than the last verse (v. 18). ${ }^{24}$

Another argument (\#4) is proffered by Barbiero, namely that the repetition of the words נשבע, יהוה in both vv. 1b-2 and v. 11 suggests that v. 11, like vv. 1b-2, begins a stanza. ${ }^{25}$ However, the repetition of נשבע is between v. $2 \mathrm{a}$ and v. $11 \mathrm{a}$ which is misaligned under the majority view. ${ }^{26}$ (The significance of the repetition of דהוה and has already been argued against in the foregoing.) A fifth textual argument (\#5) avers that the phrases (v. 10b) and לא תשב (v) function (v. 11a) as an "interstrophic hinge," thus demarcating the boundary between the two stanzas. ${ }^{27}$ While this is possible, the presence of these similar phrases can be more simply explained under the minority view-the two verses belong to the same strophe (see later).

Consider now the thematic-cohesive arguments. Barbiero argues (\#6) that each strophe is marked by a movement from person to place or vice versa ${ }^{28}$ (this assumes Barbiero's strophic divisions mentioned earlier). However, this argument suffers from the problem that the categories of person and place are rather generic. Indeed, one would expect both character and setting to be common elements in the rhetography of any psalm's narrative. Moreover, the identification of each strophe as characterised by a person or a place appears tendentious. For example, vv. 8-10 are argued to be characterised by place, ${ }^{29}$ but the strophe only mentions a place once (מנוחה) while referring to Yahweh (person) five times - once in the imperative verb, once by name, and three times by pronominal suffixes.

A similar problem is evident in another argument (\#7) by Barbiero that vv. 1b-5 and vv. 11-12 are thematically about David while vv. 6-10 and vv. 1318 are about Zion. ${ }^{30}$ The presence of v. 10 (which mentions דוד) in vv. 6-10

24 Compare this, for example, with the precise inclusio structure in Ps 122, another שיר מעלות is used only in the second colon (v. 1c) and the second last colon (v. 9a) of the psalm. Thus, even if an inclusio using דוד is intended by the psalmist, it provides at most a weak sense of closure and is unsuitable for the task that the majority view proponents put it to, cf., the methodological discussion in van der Lugt (Cantos and Strophes, 484-487 [485]) where the criterion for identifying an inclusio is "exactly corresponding positions" in the structure.

25 Barbiero, "Psalm 132," 241.

26 When the two stanzas (according to the majority view) are placed side by side, $v$. $2 \mathrm{a}$ corresponds to v. $11 \mathrm{c}$, and v. 11a corresponds to v. $1 \mathrm{~b}$.

27 Pierre Auffret, La sagasse a bâti sa maison: Études de structure littéraires dan l'Ancien Testament et spécialement dans les psaumes, OBO 49 (Göttingen: Vandenhoeck \& Ruprecht, 1982), 507; Allen, Psalms 101-150, 264.

28 Huwiler, "Patterns and Problems," 202.

29 Huwiler, "Patterns and Problems," 202.

30 Barbiero, "Psalm 132," 241. 
makes this argument difficult to maintain, especially since it is also argued that the term דוד is emphasised as part of an inclusio in v. 10a. ${ }^{31}$ Barbiero further argues (\#8) that the "ring form" cohesion between vv. 8-10 (Yahweh-peopleYahweh) suggests that v. 10 should be considered part of Stanza 1. ${ }^{32}$ However, this argument is predicated on the verbal subjects. Yet, why should one narrowly focus on verbal subjects to determine structure? Verse 10, for example, clearly emphasises both David and the משיח, while the verb is only mentioned in the second colon (v. 10b). Likewise, another argument (\#9) is made that the sequences of each of the two stanzas mirror the sequences of 2 Sam 6 (transporting the ark to Jerusalem) and 7 (the Davidic promise) respectively. ${ }^{33}$ However, if this was truly intended, v. 10 which speaks explicitly of acting for the sake of David (בעבור דוד) would be better placed in Stanza 2 (the promise to David), not Stanza 1 (the ark to Jerusalem).

Let us now turn to the last group of form-based arguments. Crow argues (\#10) that there is an "obvious formal difference between YHWH as 'Thou' (vv. 1-10), and David as 'thou' (vv. 11-12) with YHWH as 'I' (vv. 11-18, less thirdperson oracular introductions in vv. 11 and 13)." ${ }^{34}$ However, as the latter part of this quote shows, these so-called "obvious" formal differences in points of views between the two stanzas requires the third-person address of Yahweh in vv. $11 \mathrm{ab}$ and 13 to be selectively ignored. To this ignored corpus of evidence should also be added the third-person references to Yahweh in v. 2 and v. 7, and the thirdperson references to David in v. $11 \mathrm{ab}$.

Another argument (\#11) is that the majority view results in two stanzas composed of an equal number of cola. ${ }^{35}$ While this reading does result in macro (stanza-level) symmetry, it is undermined by the multiple breakdowns in micro (colon-level) symmetry already discussed. In contrast, the minority view will exhibit both macro and micro symmetry. Last, it is also argued (\#12) that, formwise, vv. 1b-10 are a petition (cf. vv.1bc, vv. 8-10) while vv. 11-18 are Yahweh's reply. ${ }^{36}$ However, these two forms are not convincing. For example, for Stanza 1, while vv. 1-2 and vv. 8-10 are overtly petitionary, vv. 6-7 are clearly not. Moreover, commentators often note an abrupt transition between v. 5 and v. 6 , thus arguing against the unity of form of Stanza $1 .{ }^{37}$ This inconsistency is also

\footnotetext{
31 See Barbiero ("Psalm 132," 240-41) who attempts to make both arguments.

32 Barbiero, "Psalm 132," 245-46.

33 Barbiero, "Psalm 132," 240.

34 Crow, Songs of Ascents, 105. See also Barbiero ("Psalm 132," 214) who argues that "vv. 1-10 are addressed to God in the second person, and vv. 11-18 speaks about God in the third person." However, this is obviously untrue of vv. 2, 5, and 7.

35 According to the Masoretic accentuation, cf., Barbiero, "Psalm 132," 240.

36 Barbiero, "Psalm 132," 240-41.

37 Gerstenberger, Psalms, Part 2, and Lamentations, 365; John Goldingay, Psalms: Volume 3, Psalms 90-150, BCOTWP (Grand Rapids: Baker Academic, 2008), 548;
} 
reflected in Stanza 2, the supposed "reply." It starts by focusing on David (vv. 11-12) but takes an extended diversion to focus on Zion (vv. 13-16) before returning to focus on David (vv. 17-18). It thus appears that there is more than meets the eye concerning the formal categorisation of the psalm than what is typically proposed by majority view proponents.

Therefore, given the above discussion, it can be seen that the various arguments used in support of the majority position are problematic on multiple fronts - textual, thematic, and formal. In light of this, evidence for the minority position should also be considered and evaluated. It is to this position that this article now turns.

\section{THE MINORITY VIEW OF THE STRUCTURE OF PSALM 132}

The ablest presenter of the minority position is Terence Fretheim who proposed that the psalm should be divided into two stanzas - Stanza $1^{*}$ (vv. 1b-9) and Stanza $2^{*}$ (vv. 10-16) - followed by a coda (vv. 17-18). ${ }^{38}$ See Figure 1 . The following observations support the minority position:

Verses $1 b-2$ and 10-11b. Unlike the majority view which has four coda (vv. 1b-2b) introducing David's oath (vv. 3-5) but only two coda (vv. 11a and 11b) introducing Yahweh's oath (vv. 11c-12d), the minority view has a lineal balance between Stanzas $1^{*}$ and $2^{*}$ since the stanzas each begins with four introductory coda (vv. 1b-2b, vv. 10-11b) prior to each oath.

Figure 1. Psalm 132's Structure according to the Minority View

\begin{tabular}{|c|c|c|c|c|c|}
\hline \multicolumn{3}{|c|}{$\underline{\text { Stanza } 1 *}$} & \multicolumn{3}{|c|}{$\underline{\text { Stanza } 2 *}$} \\
\hline \multirow[t]{2}{*}{1} & $\mathrm{~b}$ & זכור יהוה לדוד & 10 & $\mathrm{a}$ & בעבור דוד עבדך \\
\hline & $\mathrm{c}$ & את כל ענותו & & $\mathrm{b}$ & אל תשב פני משיחך \\
\hline \multirow[t]{2}{*}{2} & $\mathrm{a}$ & אשר נשבע ליהוה & 11 & $\mathrm{a}$ & נשבע יהוה לדוד \\
\hline & $\mathrm{b}$ & נדר לאביר יעקב & & $\mathrm{b}$ & אמת לא ישוב ממנה \\
\hline \multirow[t]{2}{*}{3} & $\mathrm{a}$ & אם אבא באהל ביתי & 11 & $\mathrm{c}$ & מפרי בטנך \\
\hline & $\mathrm{b}$ & אם אעלה על ערש יצועי & & $\mathrm{d}$ & אשית לכסא לך \\
\hline \multirow[t]{2}{*}{4} & $\mathrm{a}$ & אם אתן שנת לעיני & 12 & $\mathrm{a}$ & אם ישמרו בניך בריתי \\
\hline & $\mathrm{b}$ & לעפעפי תנומה & & $\mathrm{b}$ & ועדתי זו אלמדם \\
\hline 5 & $\mathrm{a}$ & עד אמצא מקום ליהוה & 12 & $\mathrm{c}$ & גם בניהם עדי עד \\
\hline
\end{tabular}

Hans-Joachim Kraus, Psalms 60-150, trans. Hilton C. Oswald, CC (Minneapolis: Fortress, 1993), 474.

38 Terence Erling Fretheim, "Psalm 132: A Form-Critical Study,” JBL 86.3 (1967): 289-300. 
40 Leow, "Structure of Psalm 132," OTE 32/1 (2019): 32-57

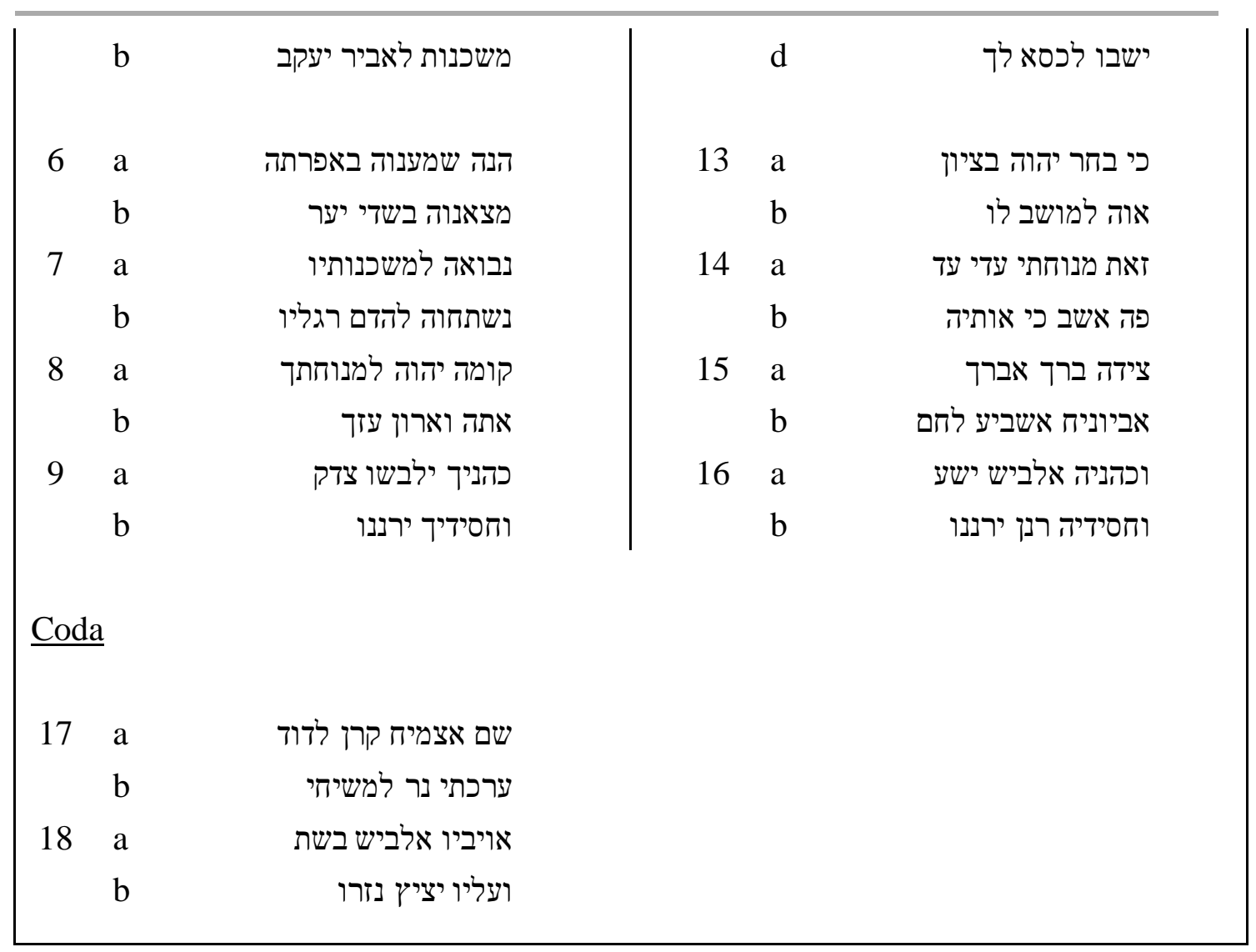

At the individual verse level, both v. $1 \mathrm{~b}$ and v. 10a begin by arguing for David's sake (לדוד in v. 1b; בעבור דוד in v. 10a). Both introductory verses also

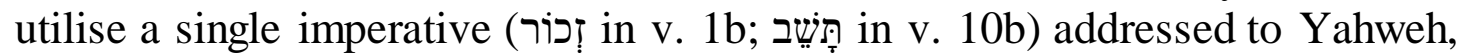
and both verses are also the only instances of enjambment in Psalm $132 .{ }^{39}$ While the minority view regarded these similarities between v. $1 \mathrm{bc}$ and v. 10 as evidence for an inclusio (which has been argued against), it is thus better to regard them as two parallel initial stanzaic lines.

Similarly, the second pair of verses (v. 2ab and v. 11ab) also correspond to each other through verbal phrases which use שבע (both nip'al qatal thirdperson masculine singular), followed by a disjunctive accent, and then by a $ל$ prepositional phrase denoting the person that the oath is made to. ${ }^{40}$ Further supporting the pairing is the semantic link between "to vow") and ("tow ("faithful oath") ${ }^{41}$ which begin vv. $2 \mathrm{~b}$ and $11 \mathrm{~b}$ respectively. Both words are also each followed by a disjunctive accent and then by an accentual unit beginning with the consonant $ל$.

39 Jan P. Fokkelman, Major Poems of the Hebrew Bible at the Interface of Prosody and Structural Analysis (Volume II: 86 Psalms and Job 4-14), SSN (Assen, Netherlands: Van Gorcum, 2000), 295.

40 “שבע:, DCH 8:240-243 [241].

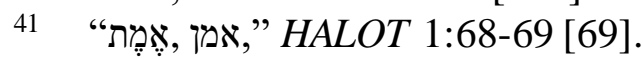


Moreover, the progression of the point of view between v. $1 \mathrm{bc}$ and v. $2 \mathrm{ab}$ also parallels that of v. 10ab and v. 11ab. Verse 1bc addresses Yahweh in the second-person and David in the third-person, while v. 2ab addresses both in the third-person. These points of view are matched exactly by v. 10ab and v. 11ab respectively. That this intra-stanzaic shift in the point of view is not incidental is suggested by the anomalous character of the third-person reference to Yahweh in v. 2 - since it is following v. $1 \mathrm{bc}$, one might expect v. 2 to mention Yahweh in the second-person instead. Finally, the minority view also allows vv. 10 and 11 to be regarded as a cohesive unit (rather than an inter-stanzaic "hinge") since the verb שוב is used in both verses. ${ }^{42}$ In light of all these parallels, the objection of Zenger (a majority view proponent) that "the supposed structural parallels between vv. 1-2 and vv. 10-11 are very superficial or non-existent"43 is manifestly an overstatement.

Verses 3-5 and 11c-12. A clear instance of structural correspondence can be seen between these verses. Both groups of verses are oaths, are comprised of six cola, and are written in first-person speech. ${ }^{44}$ The correspondence between the stanzas is further signalled textually by (a) their use of אם (vv. 3ab; 4a corresponds to v. 12a), (b) their use of עד (v. 5a corresponds to v. 12c), and (c) the fourfold use of the ל-preposition in each stanza. Verses 3-5 and 11c-12 are also "in a reciprocal relationship: David swears to YHWH and YHWH swears to David." 45 Thematically, they both focus on finding a place of enthronement: vv. 3-5 focus on David's desire to find a place to enthrone Yahweh ${ }^{46}$ whereas vv. 11c-12 focus on Yahweh's desire to place David's descendants upon the throne.

42 Indeed, as Fokkelman (Major Poems, 296) observes, the use of תשב ind and viב ind $10 \mathrm{~b}$ and $11 \mathrm{~b}$ additionally suggests that both verses belong in Stanza $2 *$ since they sound phonetically similar to ישבו (v. 12d), אשב (v. 14b), and (v. 14bed later in the stanza.

43 Hossfeld and Zenger, Psalms 3, 458.

44 Despite these similarities, the majority view offsets the two vows in its proposed structure.

45 Frank-Lothar Hossfeld, "König David im Wallfahrtspsalter," in Ein Herz so Weit wie der Sand am Ufer des Meeres: Festschrift für Georg Hentschel, ed. Susanne Gillmayr-Bucher, ETS 90 (Würzburg: Echter, 2006), 220. The English translation provided is from Hossfeld and Zenger, Psalms 3, 457.

46 This assumes two things. First, the ל-prepositions in v. 5 denote interest (i.e., "for," a common use in the HB). Second, the expressions משכנות and refer to Yahweh's place of enthronement. Concerning this second reason, note that (a) the use of משכנות in parallel with הדם רגליו in v. 7 makes this link to enthronement likely, and (b) Hossfeld and Zenger (Psalms 3, 461) reminds us that מקום is a frequent "terminus technicus for the site of the Jerusalem Temple" in the HB. 
Verses 6-7 and 13-14. Both of these sections begin with emphatic particles (הנה in v. 6; כ in v. 13). ${ }^{47}$ Note also the use of the feminine pronominal suffix twice in v. 6 and once in v. 13 (the antiphonal analysis later will show that this is not incidental). Also corresponding well to each other are the second pair of vv. 7 and 14. The former comprises two cohortative coda where the we-party expresses an intent to go to Yahweh's temple. ${ }^{48}$ Likewise, the latter also comprises two coda where Yahweh expresses his intent to rest/sit in his temple at Zion. This parallel is especially poignantly expressed in the pairing of משכנות with מנוחה in v. 7a and v. 14a, and השם רגליו in v. 7b and v. 14b. The latter pair of terms is associated with the concept of enthronement, with the verb ישב often meaning "to enthrone," in ancient Near Eastern iconography as part of kings' throne-room scenes.$^{50}$ That enthronement is clearly in view is further indicated by the re-use of the temporal phrase עד עי עי vi v. 14a which has already been unequivocally used in the context of enthronement (David's) in v. 12c.

Verses 8-9 and 15-16. Thematically, v. 8 and v. 15 complement each other. Huwiler has shown that the קום $+ל$ idiom in v. 8a should not be understood directionally ("towards") but rather as interest ("for the sake of"). ${ }^{51}$ In other words, Yahweh is being entreated in v. 8 to act for the sake of his מנוחה. Corresponding to this, v. 15 expresses Yahweh's desire to act for "her" (expressed twice by pronominal suffixes), which antecedent is clearly also the מנוחה (from v. 14a).

47 is a well-recognised strophic marker while כנה is often "occurs in strategic positions at the beginning and the end of strophes," cf. Van der Lugt, Cantos and Strophes, 77-81 [77].

48 Gerstenberger, Psalms, Part 2, and Lamentations, 365; Delbert R. Hillers, "Ritual Procession of the Ark and Ps 132," CBQ 30.1 (1968): 52; Hossfeld and Zenger, Psalms $3,462$.

49 See "ישבי," DCH 4:317-329 [318]. This is particularly the case when ישב is paired with other expressions of extended temporality such as עולם, cf., Pss 9:8; 29:10; 61:8; 102:13; $1 \mathrm{Kgs}$ 8:13; 2 Chr 6:2; Lam 5:19.

50 See Othmar Keel, The Symbolism of the Biblical World: Ancient Near Eastern Iconography and the Book of Psalms, trans. Timothy J. Hallett (New York: Crossroad, 1985), 244-80.

51 Huwiler ("Psalm 132," 204) builds on some arguments made by Hillers, "Ritual Procession." Most important of these are two observations. First, the קומ construction is never used in the HB to indicate directionality towards an object. Second, when קומ is used imperatively towards the deity in the HB, it is an entreaty for intervention. Huwiler goes one step further to propose that the ל-preposition in v. 8a operates in the same way as v. 1b, i.e., to indicate interest. See also Fokkelmann, Major Poems, 297 (n. 75). 
Finally, perhaps the clearest correspondence between Stanzas $1^{*}$ and $2^{*}$ is that between v. 9 and v. 16 :

$$
\begin{aligned}
& \text { v. } 9 \\
& \text { v. } 16
\end{aligned}
$$$$
\text { כהניך ילבשו צדק וחסידיך ירננו }
$$$$
\text { וכהניה אלביש ישע וחסידיה רנן ירננו וחסור וחנור }
$$

As Fokkelman observes, "Verse 16 is almost identical with v. 9 in spite of a long series of clever shifts." 52 Here the correspondence is not only at the syntactic level, but also on the level of noun/verb choices as well as inflection. The majority view ignores this obvious correspondence, resulting in v. 9 and v. 16 being offset, with v. 9 corresponding to v. 17 instead.

Coda. That vv. 17-18 should be considered a concluding coda to vv. 1b$16 \mathrm{~b}$ rather than just the end of Stanza 2 (according the majority view) is in the first instance clearly suggested by the use of the distal deictic term שָ ("there") in the initial position in v. $17 \mathrm{a} .{ }^{53}$ This contrasts sharply with the proximal ("here") in v. 14b. This is unexpected since vv. 17-18 consist of first-person speech, just like vv. 14-16, and so one might expect vv. 17-18 to continue the spatial perspective of vv. 14-16. However, placed in its foregrounded position in v. $17 \mathrm{a}$, שָ clearly signals a discourse shift, placing the text-immanent speaker Yahweh at a distance from the preceding verses.

Moreover, the emphasis of vv. 17-18 is clearly on the Each of its four lines explicitly mentions this anointed one ("horn," v.17a; "my anointed one," v.17b; "his enemies," v.18a; "on him; his crown," v.18b), clearly signalling the change in focus from Zion to how Yahweh will act for the משיח at Zion. Thus, the topic of vv. 17-18 contrasts clearly with vv. 13-16 where the emphasis is unmistakably on Zion - emphasised by eight-fold repetition (once with a proper noun, six times with the second-person feminine pronominal suffix, and once with the deictic).

In addition, if vv. 17-18 are recognised as a coda, then the verb לבש in v.17a is ideally structurally placed. Just like Stanzas $1 *$ and $2 *$ where לבש is placed in their penultimate colon, it is also placed in the penultimate colon of the coda. In this way, it can then serve to conclude both Stanza $1 *$ and $2 *$ which also ended by focusing on the act of clothing (in the indubitably parallel v. 9 and v. 16). A similar structural logic is also evident in the placement of the first colon of the coda (paired with the preposition ל) which mirrors how both Stanza $1^{*}$ and $2^{*}$ also begin their first colon with similar expressions. In contrast, if the majority view is followed, vv. 9-10 are paired with vv. 17-18, resulting in

52 Fokkelman, Major Poems, 293.

53 Allen, Psalms 101-150, 266; Fretheim, "Psalm 132," 299; Ernest Wendland, “The Forms and Functions of Disjunctive Parallelism in the Psalter, with Special Reference to Psalm 132," JSem 26.1 (2017): 149. 
significant mismatching of verses. Therefore, vv. 17-18 are better understood as a coda to the whole psalm than as the conclusion to vv. 11-16.

\section{STEADY RESPONSA ANTIPHONY IN PSALM 132}

The preceding arguments for the superiority of the minority view have shown that there are multiple points of lineal correspondence between Stanzas $1^{*}$ and $2 *$. In light of this, one might then ask why these correspondences are present. In response, one possibility is that these correspondences are present for aesthetic reasons, i.e., for literary artistry. However, the problem with such a hypothesis is that aesthetics, as a category, is poorly defined and as such has difficulty explaining why the specific kinds of correspondences in Psalm 132 are present. Given this, another explanation needs to be sought.

One such possibility is steady responsa. Steady responsa was a particularly "widespread mode of antiphonal performance in Antiquity." 54 It is defined as a song with two features: (1) it "divides in[to] two entities of equal length" and (2) "literary bonds are observed between parallel verse lines." 55 If Psalm 132 (in its present form in the MT) was intended to be sung according to steady responsa, it would be performed as follows:

$$
\begin{array}{llll} 
& \text { v. } 1 \mathrm{~b} & \rightarrow & \text { v. } 10 \mathrm{a} \\
\rightarrow & \text { v. } 1 \mathrm{c} & \rightarrow & \text { v. } 10 \mathrm{~b} \\
\rightarrow & \text { v. } 2 \mathrm{a} & \rightarrow & \text { v. } 11 \mathrm{a} \\
\rightarrow & \text { v. } 2 \mathrm{~b} & \rightarrow & \text { v. } 11 \mathrm{~b} \text { and so on until v. } 16 \mathrm{~b} .
\end{array}
$$

The previous section has already demonstrated how Psalm 132, under the minority view, exhibits the first feature of steady responsa, since Stanzas $1 *$ and $2 *$ are of equal colonic length. This is further corroborated by the observation that the stanzas themselves further split into equal matching strophes. However, by themselves, these observations are not enough to justify the specific hypothesis of steady responsa, since they can also be explained by aesthetic reasons.

Thus, if one wanted to argue in favour of steady responsa, one would need to focus on its second feature-literary bonds. In particular, specific kinds of literary bonds that are distinctive to steady responsa would need to be observed. In his earlier studies of other instances of complex antiphony in the HB, Amzallag has already articulated three types of literary bonds that would be present in steady responsa: ${ }^{56}$

\footnotetext{
54 Amzallag, "Musical Mode," 30.

55 Amzallag, "Musical Mode," 30.

56 See the extended discussion in Amzallag, "Musical Mode," 29-36. The presentation here uses slightly different terminology from Amzallag in order to avoid
} 
Type 1. Matching: Specific words (textual) or ideas (semantic) are repeated in the matching lines of the two halves.

Type 2. Clarification: A line from a stanza which appears incomplete or ambiguous when read linearly is clarified by its matching antiphonal line. (This would be particularly significant if it resolves debated verses in Psalm 132.)

Type 3. Enrichment: The meaning of a line is enriched in a coherent manner when it is followed by its antiphonal counterpart. This allows for a rich complex of meanings to emerge from the text, with some lines being possibly polyvalent. However, in order to provide a control, one would want to check that the antiphonal reading results in a coherent rhetoric (see Section 5).

It is literary bonds of Type 2 (Clarification) and Type 3 (Enrichment) that are distinctive to steady responsa, since these kinds of literary bonds make sense only if the matching lines from the corresponding stanzas are sung one after another. Thus, the following analysis in subsections 1-4 will focus on demonstrating that Psalm 132 exhibits inter-stanzaic clarification and enrichment when read antiphonally, thus justifying the steady responsa hypothesis. (Type 1 literary bonds have already been discussed in Section 3.) At the same time, and in further support of the steady responsa hypothesis, the following antiphonal reading will also provide solutions to some of the longstanding exegetical problems in Psalm 132.

\section{Antiphony between Ps 132:1b-2 and 10-11}

$1 b$

$$
10 a
$$

$1 \mathrm{c}$

$$
10 b
$$

$2 \mathrm{a}$

$$
11 a
$$$$
2 b
$$

$11 b$
זכור יהוה לדוד

בעבור דוד עבדך

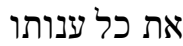

אל תשב פני משיחך

אשר נשבע ליהוה

נשבע יהוה לדוד

נדר לאביר יעקב

אמת לא ישוב ממנה
Remember, O Yahweh, in favour of David,

for the sake of David, your servant,

all of his hardships, do not turn the face of your anointed one! who swore to Yahweh,

Yahweh swore to David, he vowed to the Mighty of Jacob:

An oath, he will not turn from it:

The psalm begins in v. 1b with an entreaty for Yahweh to remember לדוד. In the HB, the "זכר + ל + noun" idiom denotes either remembrance of someone

confusion. In particular, I have avoided the vague term "correspondence" which was used earlier in my argument as a catch-all term. 
(objective) or because of someone (interest). ${ }^{57}$ Clearly, the former cannot be the case since v. 1c indicates the object of the vow (i.e., כל ענותו) through the use of an accusative marker (את). Thus, Zenger is right in observing that "David is placed in a kind of mediator role" 58 where Yahweh is being entreated to remember David's action for the benefit of someone else's sake.

This reading of the idiom is immediately confirmed by v. 1b's antiphonal counterpart, v. 10a, which contains another prepositional phrase (בעבור) which is also typically used to denote why an action is done, and not the beneficiary of the action. ${ }^{59}$ Thus, v. 10a clarifies v. $1 \mathrm{~b}$ (Type 2 bond). It also further develops it (Type 3 bond) using a structure common to biblical parallelism: $\mathrm{AB}$ (v. 1b) $\rightarrow$ $\mathrm{B}^{\prime} \mathrm{C}$ (v. 10a), where the two prepositional phrases correspond to B and $\mathrm{B}^{\prime}$. The addition of $\mathrm{C}$, the appositional phrase עבדך, thus allows the psalm to begin not just with an entreaty, but also by identifying the relative power dynamic between Yahweh and David, namely, that between a sovereign and his servant.

The object of the remembrance is then introduced in v. 1c-David's hardships (ענות), referring to the actions described in the vow later in vv. 3-5. ${ }^{60}$ However, if antiphony is absent, vv. 1bc would be incomplete since it is not David whom the entreaty is for and thus the actual beneficiary of the entreaty would be missing from vv. 1bc. Indeed, if one were to follow a linear reading of the psalm, the earliest point where a possible beneficiary for Yahweh's actions is explicitly mentioned is either in v. 8a (Zion) or v. 10b (משיח). However, with antiphony, v. $10 \mathrm{~b}$ completes (Type 2 bond) the entreaty by stating the beneficiary: the משיח. Yahweh is thus called to respond to the petition of an anointed one ${ }^{61}$ because of what David has done.

The next colon to be performed would be v. 2a, which begins with a relative particle אשאר. Despite the antiphonal mixing of coda, there is no ambiguity to the particle's referent since it is clearly David, not the anointed one, who is swearing to Yahweh. As described previously, there is significant syntactical parallelism between v. $2 \mathrm{a}$ and its antiphonal counterpart v. 11a. This similarity in syntax helps to enrich the rhetoric (Type 3 bond) by bringing out

\footnotetext{
57 See "זכר I," DCH 3:105-9 [107].

58 Hossfeld and Zenger, Psalms 3, 460.

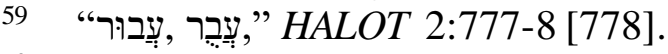

60 Goldingay (Psalms 90-150,545) helpfully reminds us that "There is only one place in the OT where a word from 'annâ II unequivocally applies to David, 'ónŷ̀ in 1 Chron. 22:14, where the reference matches the present context [of Ps. 132] very well." See also Gerstenberger, Psalms, Part 2, and Lamentations, 364; Hossfeld and Zenger, Psalms 3,461 .

61 שנה the idiom "to someone" also appears in $1 \mathrm{Kgs} 2: 16-17,20 ; 2 \mathrm{Kgs}$ 18:24; Isa 36:9. In every instance, it means to turn down the petition of someone.
} 
the key difference between the cola-the reciprocal relationship between Yahweh and David where they swear to each other.

Notwithstanding this reciprocity, recall that v. 10a has already indicated that the relationship between the Yahweh and David is asymmetrical (sovereign $\leftrightarrow$ servant). It can then be seen that this asymmetry is carried through into the next line pair of vv. $2 \mathrm{~b}$ and $11 \mathrm{~b}$. Both lines begin with a word associated with vows: אמת and אמדת emphasises that Yahweh's vow is more faithful and trustworthy than the mere נדר נדר of David (a more common and neutral term). ${ }^{62}$ Moreover, just as v. 2b elaborates on v. 2a by way of providing an alternative honorific for Yahweh, ${ }^{63}$ thus highlighting Yahweh's superior eminence, v. 11b elaborates on v. 11a by further emphasising that Yahweh will not turn from his faithful vow. So, while the antiphony begins in vv. 2a and 11a by demonstrating how Yahweh and David have each taken a vow to each other, the next lines (vv. $2 \mathrm{~b}$ and $11 \mathrm{~b}$ ) both stress Yahweh's superior status and faithfulness (Type 3 bond).

\section{Antiphony between Ps 132:3-5 and 11c-12d}

$3 a$

$$
11 c
$$

$3 b$

$11 d$

$4 \mathrm{a}$

$12 a$

$4 \mathrm{~b}$

$12 b$

$5 \mathrm{a}$

$12 c$

$5 b$

$12 d$
אם אבא באהל ביתי

מפרי בטנך

אם אעלה על ערש יצועי

אשית לכסא לך

אם אתן שנע לעיני

אם ישמרו בניך בריתי

לעפעפי תנומה

ועדתי זו אלמדם ועוע

עד אמצא מקום ליהוה ועדות

גם בניהם עדי עד

משכנות לאביר יעקב

ישבו לכסא לך
"If I go into the tent of my house,

"One from the fruit of your loins,

if I go up upon the resting place of my bed,

I will place upon your throne.

if I give sleep to my eyes,

If they will keep, your sons, my covenant,

to my eyelids, slumber,

and my testimony, which I will teach them, until I find a place for Yahweh,

Even their sons for ever and ever,

a grand dwelling for the Mighty of Jacob."

they will sit upon your throne."

In light of the series of אם in vv. 3a, 3b, and 4a, commentators have typically understood vv. 3-4 to exhibit synonymous parallelism, with v. 3 being understood in light of v. 4. Hence, the idioms of "going into the tent" and "going upon the bed" have often been understood to mean "to enjoy rest." ${ }^{64}$ However,

62 Robin Wakely, "נדר," NIDOTTE 3:37-42.

63 Charles Augustus Briggs and Emilie Grace Briggs, The Book of Psalms, 2 vols., ICC (New York: Scribner's Sons, 1907), 2:469; Gerstenberger, Psalms, Part 2, and Lamentations, 365; Kraus, Psalms 60-150, 479.

64 E.g., Booij, "Psalm 132," 80; Gunkel, Die Psalmen, 566; Hossfeld and Zenger, Psalms 3, 461. 
such a reading is extremely repetitive since the same thing is said four times (even more so with the LXX which has an extra verse in v. 4). ${ }^{65}$ While synonymous parallelism is common in the Psalter, fourfold repetition is very rare. $^{66}$

There is another possible reading of v. 3 which would obviate this tedious repetition, and that is to understand v. 3 as periphrasis for sexual intercourse, following the Targum to the Psalms. ${ }^{67}$ Certainly one of the reasons why one might go into one's house/tent (v. 3a) is to lie with one's wife (e.g., 1 Sam 11:11). This is further suggested by the use of the nouns ערש and (cf., Prov 7:16; Song 1:16, Gen 49:4; 1 Chr 5:1), especially when they are used in conjunction with the verb עלה (see esp. Gen 49:4, cf. also Isa 57:8) and the preposition על (cf., Gen 31:10, 12).

This reading is further corroborated by an antiphonal reading of v. 3 with v. 11cd (Type 2 bond). The expression מפרי בטנך draws the attention to the product of David's sexual intercourse since it reflects the idea that the man's seed has developed into a fruit in the mother's womb. ${ }^{68}$ This contrast between sexual intercourse and its product coheres well with the asymmetric rhetoric already seen in vv. 1b-2b and 10a-11b, that is, while David swears not to partake in sexual intercourse, Yahweh is depicted as trumping that vow by stating his own commitment to enthrone David's sons, the "fruit" of such intercourse. This trumping is also reflected in the spatiality of the paired verses. While David rejects going onto his bed, Yahweh affirms that he will place David's son onto the throne. Thus, the relationship between the antiphonal pairs (vv. 3a and 11cd) is elaborative and contrastive (Type 3 bond).

When the antiphony between vv. 4 and $12 \mathrm{ab}$ is considered, the dialogue between Yahweh and David further deepens (Type 3 bond). David is depicted as intensifying his oath by not only eschewing sexual pleasure, but now even by eschewing sleep itself (v. 4). However, the antiphonal response of v. $12 \mathrm{ab}$ is

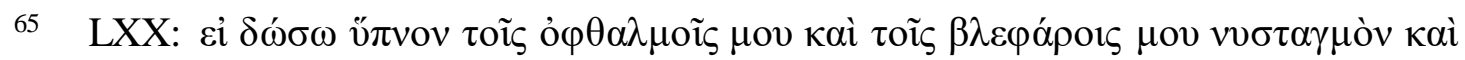

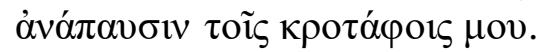

66 Goldingay (Psalms, 547) comments that this is "unnecessary repetition." This repetition has led Briggs and Briggs (Book of Psalms, 2:467) to deem v. 4 as "a gloss of intensification." Boyo G. Ockinga ("An Example of Egyptian Royal Phraseology in Psalm 132," BN 11 (1980): 38-42) attempts to find a parallel for vv. 3-4 in Egyptian royal phraseology, but there are no Egyptian texts which exhibit fourfold synonymous parallelism either. This is likewise the case for the Sumerian parallel quoted by Booij, "Psalm 132," 80. Understanding vv. 3-4 as speaking of two different things (sex and sleep) avoids the tedium entirely, while still maintaining the sense of David's determination.

67 The Targum translates v. 3a as אין איעול על אתתי ("I will not approach my wife").

68 Marianne Grohmann, Fruchtbarkeit und Geburt in den Psalmen, FAT 53 (Tübingen: Mohr Siebeck, 2007), 171. 
contrastive, signalled now by the use of a final אם in v. 12a which "answers" the third אם in v. 4a. The antiphonal dialogue between the voices of David and Yahweh suggests that it is not David's avoidance of sleep or sexual intercourse that is most essential, but the observance of Yahweh's covenant and testimony, which Yahweh himself shall take the initiative to teach.

Finally, in v. 5 and v. $12 \mathrm{~cd}$, both vows come to their end as the goal of each vow is stated. This telic emphasis is highlighted by the twin use of the preposition $ל$ in each pair of coda. Both antiphonal pairs of lines exhibit interesting phonological wordplay which serves to emphasis the asymmetric rhetoric. The antiphonal pair of vv. 5a and $12 \mathrm{c}$ begins with a single $7 \mathrm{y}$, and then ends with a double עד (s). This doubling serves to create a phonetic emphasis which complements the semantic contrast between Yahweh who gives David's sons a place forever and ever, in contrast to David who will merely not rest until he finds a place for Yahweh (Type 3 bond). The next pair of vv. $5 \mathrm{~b}$ and $12 \mathrm{~d}$ each begins with a word that is associated with dwelling and ends with a prepositional phrase. However, just like the previous word pair, while v. 5b ends with a single ל-preposition, v. 12d ends with twin ל-prepositions. This repetition again serves to highlight the superiority of what Yahweh gives to David (i.e., a throne, כסאט) when compared to what David gives to Yahweh (dwelling, משכנות)(Type 3 bond).

\section{$3 \quad$ Antiphony between Ps 132:6-9 and 13-16}

$6 \mathrm{a}$ $13 a$
הנה שמענוה באפרתה

כי בחר יהוה בציון
Behold, we heard of her in the farmlands! $!^{69}$

Indeed, Yahweh chose Zion,

69 are typically interpreted as denoting Bethlehem and Kiriathjearim respectively, cf., Arthur Robinson, "Do Ephrathah and Jaar Really Appear in Psalm 132.6?," ZAW 86 (1974): 220-21 for a survey of the interpretive options. The identification of אפרתה as Bethlehem is based on similarities with Gen 35:19; 48:7, and Mic 5:1. However, since these texts are all careful to qualify that the אפרתה mentioned is Bethlehem, they suggest that אפרתה, when used by itself (as it is in Ps 132:6), should be regarded as a generic term. This is likewise the case for שדי יער (מיער whose identification with Kiriath-jearim (קרית יערים) is predicated on the use of יער in both phrases. However, יער is a common and generic word in the HB that typically refers to woods and is frequently used in place names, cf., I. Cornelius, "עַע,," NIDOTTE 2:492-494.

Given this, one should follow the suggestion by Delitzsch (and others) that these terms are generic in nature, with פפרתה referring to cultivated lands (from the verb פרה יערה) and with שדי יער referring plainly to fields of trees, i.e., uncultivated lands. Thus, אפרתה and שדי יער form a merism, referring to all Israel. See Franz Delitzsch, Biblical Commentary on the Psalms, trans. Francis Bolton, 3 vols. (Edinburgh: T\&T Clark, 1871), 3:313; Cuthbert C. Keet, A Study of the Psalms of Ascents: A Critical and Exegetical Commentary on Psalms 120-134 (London: Mitre, 1969), 90; Helmut Lamparter, Das Buch der Psalmen II, BAT 15 (Stuttgart: Calwer, 1959), 316. 


\begin{tabular}{|c|c|c|}
\hline $6 b$ & מצאנוה בשדי יער & We learned of her in the wooded fields! $!^{70}$ \\
\hline $13 b$ & אוה למושב לו & He desired her for a dwelling for himself. \\
\hline $7 \mathrm{a}$ & נבואה למשכנותיו & Let us go to his grand dwelling! \\
\hline $14 a$ & זאת מנוחתי עדי עד & "This is my resting place forever and ever, \\
\hline $7 b$ & נשתחוה להדם רגליו & Let us bow to the footstool of his feet! \\
\hline $14 b$ & פה אשב כי אותיה & Here I will be enthroned for I desired her. \\
\hline $8 \mathrm{a}$ & קומה יהוה למנוחתך & Arise, Yahweh, because of your resting place, \\
\hline $15 a$ & 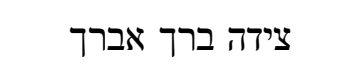 & Her provisions I will surely bless, \\
\hline $8 b$ & אתה וארון עזך & you and the ark of your strength. \\
\hline $15 b$ & אביוניח אשביע לחם & Her poor I will satisfy with bread. \\
\hline $9 \mathrm{a}$ & כהניך ילבשו צדק & Let your priests put on righteousness, \\
\hline $16 a$ & וכהניה אלביש ישע & and her priests I will clothe with salvation, \\
\hline $9 b$ & 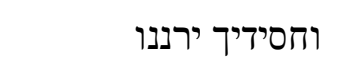 & and your devoted ones shout for joy, \\
\hline $16 b$ & וחסידיה רנן ירננו & $\begin{array}{l}\text { and her devoted ones } \\
\text { they will surely shout with joy. }\end{array}$ \\
\hline
\end{tabular}

Perhaps the most challenging exegetical problem in Psalm 132 is the identity of the referents of the two pronominal suffixes in v. 6a and v. 6b. At the heart of the debate is the problem of there being no suitable feminine singular referent for the suffixes in vv. 3-5 which immediately precede v. 6 . Thus, commentators have had to look further afield for the referent, and have proposed the following solutions:

1. The ark (from v. $8 \mathrm{~b}$; the most popular view) $;^{71}$

2. David's vow (from v. $2 \mathrm{a}) ;{ }^{72}$

\footnotetext{
70 See n. 69.

71 This popular view is predicated on the mention of the ark later in v. 8a, as well as by reading v. 6 as allusive of 2 Sam 6 (cf. Hossfeld and Zenger, Psalms 3, 456). However, this interpretation raises four problems. First, it requires a particular reading of שדי יער as denoting Bethlehem and Kiriath-jearim respectively, but neither of these identifications is without its own difficulties (see n. 69). Second, the ark is only mentioned explicitly later in v. 8b, and hinted at in v. 7b. Third, if one follows the storyline of 2 Sam 6, it is somewhat a stretch to say that the ark was "found" (מצא) since the knowledge of its location does not appear to have been lost. Fourth, the ark is typically referred to as masculine in the HB (except for 1 Sam 4:17 and 2 Chr 8:11).

72 Mitchell Dahood (Psalms III, 101-150, AB 17a (New York: Doubleday, 1970), 244) argues that the suffixes refer back to David's vow in v. 2 since the Hebrew noun for "oath" (שָׁבוּעָה) is feminine. Undermining this argument is the fact that v. 2 does not

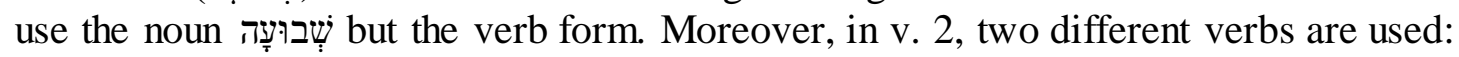


3. David's hardship in general (from vv. $1-5) ;^{73}$

4. Zion (from v. 13). ${ }^{74}$

However, this lack of a referent in the immediate co-text is obviated if we read the text antiphonally. The referent of the pronominal suffix in v. 6a would then be immediately clarified to be Zion by its antiphonal counterpart (v. 13a)(Type 2 bond). This solution is attractive because of its proximity and its simplicity. In addition, unlike the view which identifies the pronominal suffixes with the ark, there is a good grammatical match between the suffixes and Zion, the latter being consistently referred to as a feminine singular in the HB as well as in Psalm 132 (Zion is denoted with a third-person feminine singular pronominal suffix six times in vv. 13b-16b, and once by a feminine singular proximal deictic in v. 14a).

Not only is this significant textual issue resolved by the antiphony, the literary relationship between v. 6 and v. 13 makes good sense. Verse 6 states that the we-party has heard/learned of Zion; but what exactly about Zion have they heard and learned about? Verse 13 clarifies that it is Yahweh's choice of Zion as his dwelling that they have heard (Type 2 bond). Recognising this antiphonal relationship allows v. 6 and v. 13 to be recognised for what they are-discourse pivots away from the acts of vowing towards an emphasis on Zion (the space which both vows focus on).

This artful pairing is repeated between the next antiphonal pair of v. 7 and v. 14. The exhortation of the we-party to go to Yahweh's משכנות (v. 7a) is justified by Yahweh's statement that it is indeed his מנוחה forever (v. 14a) (Type 3 bond). Indeed, "the pilgrims follow where their LORD has gone." 75 Likewise, as earlier described, the exhortation of the we-party to go to Yahweh's footstool (הדם , v. 7b) is perfectly matched by the description that Yahweh will be enthroned (verb ישב, v. 14b) at Zion (Type 3 bond). ${ }^{76}$ The complementary intensifying dynamic then continues in the antiphony between v. 8 and v. 15. As

נדר שבע שבע (נֶדר) However, for the latter, its noun form isculine and it is more common in the HB than שֶׁבוּעָה

73 Kruse ("Psalm 132," 293) interprets the feminine suffixes as "it" and thus "referring vaguely to the object of the preceding verses, the aim of David's vows and efforts ... whatever the gender of the preceding nouns is." However, given the atypical nature of Kruse's argument, this argument should be treated as an argument of last resort, and only used if a feminine referent for the suffixes cannot be found.

74 See Michael Emmendörffer, Der ferne Gott: Eine Untersuchung der alttestamentlichen Volksklagelieder vor dem Hintergrund der mesopotamischen Literatur, FAT 21 (Tübingen: Mohr Siebeck, 1996), 246. This option suffers from a similar problem to the ark option-Zion is not explicitly mentioned until v. 13. This problem will be addressed through antiphony.

75 Mays, Psalms, 411.

76 See n. 50. 
earlier mentioned, v. 8a should be understood as a call to Yahweh to act for Zion. This call is enriched by the confirmatory answer from Yahweh in v. 15a that Yahweh will indeed act to bless Zion's provisions. Likewise, this is the case for v. $8 \mathrm{~b}$ and v. $15 \mathrm{~b}$, except that the promise now is to satisfy Zion's poor with bread (Type 3 bond).

Finally, the antiphony between the two stanzas comes to a clear climax in the antiphony between v. 9 and v. 16. This is the first time in the antiphony where the matching lines are almost identical. Why is this the case only for these two verses at the end of the two stanzas? It is likely that this near repetition serves to signal the conclusion of the antiphony between the two stanzas (Type 2 bond). The near repetition also serves as a climax since the subtle changes from v. 9a to v. $16 \mathrm{a}$ and from v. $9 \mathrm{~b}$ to v. $16 \mathrm{~b}$ serve to create a crescendo-like parallelism. In response to the we-party's request for the priests to be clothed with righteousness, Yahweh answers in the first-person that he will do so, and clothe them additionally with salvation. Likewise, in response to the we-party's request that the hasidim shout for joy, Yahweh responds in confirmation yet escalating it through the use of the intensifying infinitive absolute. ${ }^{77}$

\section{$4 \quad$ Post-Antiphony Coda (Ps 132:17-18)}

As earlier discussed in Section 3, the use of שָׁ as a discourse marker and the thematic shift to focus back on David (as opposed to Zion which was the focus of vv. 6-9 and vv. 13-16) suggest that vv. 17-18 act as a separate coda rather than a continuation of vv. 13-16. Moreover, this coda was likely not sung according to steady responsa (i.e., v. $17 \mathrm{a} \rightarrow$ v. $18 \mathrm{a} \rightarrow$ v. $17 \mathrm{~b} \rightarrow$ v. $18 \mathrm{~b}$ ) since it does not exhibit the clarification (Type 2 bond) or enrichment (Type 3 bond) characteristic of steady responsa. As such, this concluding coda was probably sung linearly according to verse order, either by both choirs singing together or by them alternating in plain antiphony.

In addition, the structural parallels between the coda and the Stanzas 1* and $2^{*}$ also argue against complex antiphony in the coda. The coda places משיח in the and the verb לבש inst, second, and penultimate cola respectively,just like Stanzas $1 *$ and $2 *$. However, if the coda was sung antiphonally, these structural parallels would be wrecked. Instead, these structural parallels between vv. 17-18 (the coda) and vv. 1b-16 (the main antiphonal section) suggest that the coda probably functions with a concluding function with regard to the main antiphonal section (see following discussion).

77 GKC §45a. See also Fretheim, "Psalm 132," 293. 


\section{E PSALM 132'S ANTIPHONAL RHETORIC}

Having shown how Psalm 132 exhibits Type 2 and Type 3 literary bonds characteristic of steady responsa, the psalm can now be further reviewed in order to see if the antiphony results in a coherent rhetoric. The antiphonal performance of the psalm begins in vv. 1b-2 and 10-11b with an entreaty. Yahweh is called upon to act for the משיח (identified through antiphony) for the sake of David. In presenting this petition, the singers are careful to outline the relationship between Yahweh and David: it is reciprocal but not one of equals. This deliberate honouring of Yahweh (as the אביר יעקב who does not שמת מבת from his) over David (עis עבד) sets a humble and flattering tone, which is contextually appropriate in a petitionary setting (suggested by the use of the idiom עברד and (אל תשב פני משיחך.).

The antiphony between vv. 3-5 and 11c-12d then continues this flattering rhetoric by depicting the superiority of Yahweh's vow over David's. While David merely pledges to eschew sexual intercourse and rest until (ע) he finds a dwelling for Yahweh (i.e., Zion), Yahweh pledges to place the "fruits" of that intercourse -David's children - upon Zion's throne until eternity (עדי עד). By articulating the two vows, the psalm presents two reasons why Yahweh should act "for David's sake," namely, to reward David's faithfulness in establishing a dwelling place for Yahweh (i.e., Zion), and to be faithful to Yahweh's own promise to David to establish a throne at Zion. Both vows serve to motivate Yahweh to act for the Davidic משיח.

At the same time, both vows centre upon the space of Zion, presented in the psalm as where the Davidic dynasty reigns (this is especially clear in vv. 1718 ) as well as where Yahweh himself reigns. Given this emphasis on Zion in the vows, the singers who began the psalm ${ }^{79}$ shift in v. 6 away from focusing on David towards focusing on Zion instead. This change in the rhetoric is signalled by הנה (v. 6a) and (v. 13a). Verse 6 begins with the singers noting that they have heard of Zion wherever they dwelt in Israel ${ }^{80}$ (v. 6), specifically, that Yahweh has chosen to dwell in Zion (v. 13). They are thus motivated to go on pilgrimage to Zion to worship at Yahweh's throne (v. 7), where Yahweh has chosen to be enthroned forever (v. 14). Then, in vv. 8-9, the pilgrims entreat

78 See n. 61. Fokkelman tries to capture this asymmetrical dynamic by describing the psalm as a "combat de générosité, which David loses" (Major Poems, 293). While this is a poignant picture, portraying Yahweh and David trying to outdo each other is not in sync with the rhetoric of the psalm which, after all, seeks to entreat Yahweh to act on behalf of the משיח. Instead, it might be better to argue that the rhetoric is deliberately both humble and flattering towards Yahweh in line with petitionary rhetoric.

79 Gerstenberger, Psalms, Part 2, and Lamentations, 364.

80 See n. 69. 
Yahweh to act for Zion, especially its priests and the hasidim. ${ }^{81}$ Yahweh responds positively (through antiphony), confirming that he will indeed bless Zion (v. 15), and specifically bless her priests and the hasidim. Yahweh's response is presented as rich and generous, continuing the earlier flattering petitionary rhetoric.

The rhetoric of the psalm draws to a close in the coda. Critically, the preceding discussion has shown that the language of the coda is meant to parallel both the beginnings (לשיח, (לשוד) and ends Stanzas 1* and 2*. These two parallels suggest that the coda is meant to act as an answer to both the petition for the משיח (vv. 1b-2, 10-11b) at the stanzas' beginnings ${ }^{82}$ as well as the pilgrims' entreaty for Zion at the stanzas' ends (vv. 8-9, 15-16). Indeed, by starting with the discourse marker wֶ, the coda indicates that Zion is the setting within which Yahweh will act. At the same time, the coda focuses on the many blessings that Yahweh will enact for the משיח. In this way, the coda acts as a climax and conclusion for the entire psalm: The Davidic משיח is blessed together with Zion, the site of the Davidic throne. Both are blessed by Yahweh the King who himself is enthroned at Zion. At the same time, the singers also partake of that blessing as they journey to and advocate for the משיח's and Zion's welfare.

\section{F CONCLUSION}

This article sought to demonstrate how complex antiphonal readings have the potential to provide non-linear structural solutions to existing exegetical problems. This was demonstrated in the case of Psalm 132. Detailed considerations of the structure of the psalm led one to adopt the minority view on the psalm's structure, which, in turn, commended a steady responsa antiphonal reading of the psalm. By analysing the psalm through such a lens, a number of difficulties with the text were resolved in a straightforward fashion, including the long-standing challenge of the referent of the pronominal suffixes in v. 6. In addition, the antiphonal reading also shed significant interpretative light onto the psalm's rhetoric. The psalm's antiphonal stanzas are generally petitionary in nature (though not at every point), seeking for the welfare of the Davidic משיח and Zion (the site of the Davidic throne). The petition is answered by Yahweh who himself is enthroned at Zion.

\section{BIBLIOGRAPHY}

Allen, Leslie C. Psalms 101-150. Revised ed. WBC 21. Waco, TX: Word, 2002.

81 Hossfeld and Zenger (Psalms 3, 463) observe that the hasidim are "not a special group among the people but, with the priests, constitute the whole of Israel (merism)." This suggests that the hasidim could very well be referring to the actual singers of the psalm who come from all over Israel (cf., v. 6a and n. 69).

82 Fretheim, "Psalm 132," 299; Josef Schreiner, Sion-Jerusalem Jahwehs Königssitz: Theologie der heiligen Stadt im Alten Testament, SANT 7 (Munich: Kösel, 1963), 175. 
Amzallag, Gérard Nissim. "The Musical Mode of Writing of the Psalms and its Significance." OTE 27.1 (2014): 17-40.

_. "Psalm 87 and the Cosmopolitan Musical Worship of YHWH." VT 64 (2014): 361-81.

—. "The Meaning of Todah in the Title of Psalm 100." ZAW 126.4 (2014): 53545.

-. "Praise or Antiphonal Singing?: The Meaning of להודות Revisited." HS 56.1 (2015): 115-28.

. "Psalm 67 and the Cosmopolite Musical Worship of YHWH." BBR 25 (2015): 31-48.

- "Foreign Yahwistic Singers in the Jerusalem Temple?: Evidence from Psalm 92." SJOT 31.2 (2017): 213-35.

Amzallag, Gérard Nissim, and Mikhal Avriel. "Complex Antiphony in Psalms 121, 126 and 128: The Steady Responsa Hypothesis.” OTE 23.3 (2010): 502-18.

- "The Canonic Responsa Reading of Psalm 114 and Its Theological Significance." OTE 24 (2011): 303-23.

_. "Responsive Voices in the Song of the Sea (Exodus 15:1-21)." JBQ 40.4 (2012): 211-24.

. "Psalm 122 as the Song Performed at the Ceremony of Dedication of the City Wall of Jerusalem (Nehemiah 12, 27-43)." SJOT 30.1 (2016): 44-64.

Amzallag, Nissim, and Shamir Yona. "The Unusual Mode of Editing of KTU 1.65." UF 45 (2014): 35-48.

_. "What Does 'Maskil' in the Heading of a Psalm Mean?" ANES 53 (2016): 4157.

Auffret, Pierre. La sagasse a bâti sa maison: Études de structure littéraires dan l'Ancien Testament et spécialement dan les psaumes. OBO 49. Göttingen: Vandenhoeck \& Ruprecht, 1982.

Barbiero, Gianni. "Psalm 132: A Prayer of 'Solomon." CBQ 75.2 (2013): 239-58.

Booij, Thijs. "Psalm 132: Zion's Well-Being." Biblica 90.1 (2009): 75-83.

Briggs, Charles Augustus, and Emilie Grace Briggs. The Book of Psalms. 2 vols. ICC. New York: Schribner's Sons, 1907.

Brueggemann, Walter, and William H. Jr. Bellinger. Psalms. NCBC. New York: Cambridge University Press, 2014.

Crow, Loren D. Songs of Ascents (Psalms 120-134): Their Place in Israelite History and Religion. SBLDS 48. Atlanta: SBL Press, 1996.

Dahood, Mitchell. Psalms III, 101-150. AB 17a. New York: Doubleday, 1970.

Delitzsch, Franz. Biblical Commentary on the Psalms. Translated by Francis Bolton. 3 vols. Edinburgh: T\&T Clark, 1871.

Emmendörffer, Michael. Der ferne Gott: Eine Untersuchung der alttestamentlichen Volksklagelieder vor dem Hintergrund der mesopotamischen Literatur. FAT 21. Tübingen: Mohr Siebeck, 1996.

Fokkelman, Jan P. Major Poems of the Hebrew Bible at the Interface of Prosody and Structural Analysis (Volume II: 86 Psalms and Job 4-14). SSN. Assen, Netherlands: Van Gorcum, 2000.

Fretheim, Terence Erling. "Psalm 132: A Form-Critical Study." JBL 86.3 (1967): 289300. https://doi.org/10.2307/3263009.

Geller, Stephen A. Parallelism in Early Biblical Poetry. HSM 20. Missoula, MT: Scholars Press, 1979. 
Gerstenberger, Erhard S. Psalms, Part 2, and Lamentations. FOTL 15. Grand Rapids: Eerdmans, 2001.

Goldingay, John. Psalms: Volume 3, Psalms 90-150. BCOTWP. Grand Rapids: Baker Academic, 2008.

Grohmann, Marianne. Fruchtbarkeit und Geburt in den Psalmen. FAT 53. Tübingen: Mohr Siebeck, 2007.

Gunkel, Hermann. Die Psalmen. Göttingen: Vandenhoeck \& Ruprecht, 1929.

Hillers, Delbert R. "Ritual Procession of the Ark and Ps 132." CBQ 30.1 (1968): 4855.

Hossfeld, Frank-Lothar. "König David im Wallfahrtspsalter." Pages 219-33 in Ein Herz so Weit wie der Sand am Ufer des Meeres: Festschrift für Georg Hentschel. Edited by Susanne Gillmayr-Bucher. ETS 90. Würzburg: Echter, 2006.

Hossfeld, Frank-Lothar, and Erich Zenger. Psalms 3: A Commentary on Psalms 101150. Translated by Linda M. Maloney. Hermeneia. Minneapolis: Fortress, 2011.

Huwiler, Elizabeth F. "Patterns and Problems in Psalm 132." Pages 199-215 in Listening Heart: Essays in Wisdom and the Psalms in Honour of Roland E. Murphy. Edited by Kenneth G. Hoglund. JSOTSup 58. Sheffield: Sheffield Academic, 1987.

Keel, Othmar. The Symbolism of the Biblical World: Ancient Near Eastern Iconography and the Book of Psalms. Translated by Timothy J. Hallett. New York: Crossroad, 1985.

Keet, Cuthbert C. A Study of the Psalms of Ascents: A Critical and Exegetical Commentary on Psalms 120-134. London: Mitre, 1969.

Kraus, Hans-Joachim. Psalms 60-150. Translated by Hilton C. Oswald. CC. Minneapolis: Fortress, 1993.

Kruse, Heinz. "Psalm 132 and the Royal Zion Festival." VT 33.3 (1983): 279-97.

Kugel, James L. The Idea of Biblical Poetry: Parallelism and its History. Baltimore; London: Johns Hopkins University Press, 1998.

Laato, Antti. "Psalm 132 and the Development of the Jerusalemite/Israelite Royal Ideology." CBQ 54.1 (1992): 49-66.

Lamparter, Helmut. Das Buch der Psalmen II. BAT 15. Stuttgart: Calwer, 1959.

Lugt, Pieter van der. Cantos and Strophes in Biblical Hebrew Poetry with Special Reference to the First Book of the Psalter. OTS 53. Leiden; Boston: Brill, 2006.

Mays, James Luther. Psalms. IBC. Louisville: Westminster John Knox, 1994.

Moshavi, Adina. Word Order in the Biblical Hebrew Finite Clause. LSAWS 4. Winona Lake, IN: Eisenbrauns, 2010.

Ockinga, Boyo G. "An Example of Egyptian Royal Phraseology in Psalm 132." BN 11 (1980): 38-42.

Robinson, Arthur. "Do Ephrathah and Jaar really appear in Psalm 132 6?" ZAW 86 (1974): 220-22.

Schreiner, Josef. Sion-Jerusalem Jahwehs Königssitz: Theologie der heiligen Stadt im Alten Testament. SANT 7. Munich: Kösel, 1963.

Slotki, Israel W. "Antiphony in Ancient Hebrew Poetry.” JQR 26.3 (1936): 199-219. https://doi.org/10.2307/1452409.

Weiser, Artur. The Psalms: A Commentary. Translated by Herbert Hartwell. OTL. Philadelphia, PA: Westminster Press, 1962. 
Wendland, Ernest. "The Forms and Functions of Disjunctive Parallelismin the Psalter, with Special Reference to Psalm 132." JSem 26.1 (2017): 123-57. https://doi.org/10.25159/1013-8471/2441.

Wen-Pin Leow, Wycliffe Hall, University of Oxford, 54 Banbury Road, Oxford, OX2 6PW; Email: wenpinleow@gmail.com; ORCID: https://orcid.org/00000002-2894-384. 